COMMENTARY ON COVID-19 AND THE Food SySTEM

\title{
Florida fruit and vegetable growers' adaptation and response to COVID-19
}

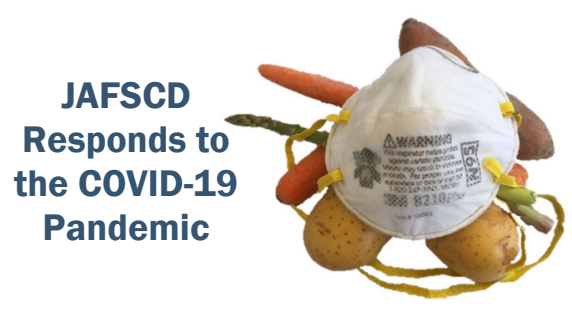

\author{
Catherine G. Campbell ${ }^{\text {a* }}$ and Gene McAvoy ${ }^{\mathrm{b}}$ \\ University of Florida
}

Submitted July 31, 2020 / Published online August 19, 2020

Citation: Campbell, C. G., \& McAvoy, G. (2020). Florida fruit and vegetable growers' adaptation and response to COVID-19. Journal of Agriculture, Food Systems, and Community Development, 9(4), 165-169. https://doi.org/10.5304/jafscd.2020.094.032

Copyright (C) 2020 by the Authors. Published by the Lyson Center for Civic Agriculture and Food Systems. Open access under CC-BY license

\begin{abstract}
While Florida is known for theme parks and beaches, its agricultural sector is the second largest industry in the state and accounts for a substantial proportion of the United States' annual production of many fruit and vegetable crops. Florida's farmers have capitalized on the fact that Florida is a top tourism destination, with 70-80\% of large producers' sales targeting the theme-park, hotel, restaurant, and cruise line industries that were decimated by stay-at-home orders. With the exception of citrus, peak harvest for these crops is from March to May, which coincided exactly with the onset of the COVID-19 pandemic in the spring of 2020. Florida producers were left with hundreds of millions of pounds of produce with no available market. Florida farmers utilized innovative sales and market opportunities to sell as much of their highly perishable produce as they could. In addition, despite substantial personal hardship and financial losses, producers paid to harvest and transport produce to food banks and other hunger-relief organizations that were overwhelmed with demand from people who recently lost their jobs or were furloughed due to the closures of restaurants, hotels, theme parks, and cruise lines due to the pandemic. However, with the sheer volume of perishable produce left without buyers, some crops simply had to be tilled under or terminated. The COVID-19 pandemic increased awareness of and demand for Florida

a * Corresponding author: Catherine G. Campbell, Assistant Professor, Community Food Systems; Family Youth and Community Sciences Department, College of Agricultural and Life Sciences, University of Florida, Institute of Food and Agricultural Sciences, Mid-Florida Research and Education Center; 2725 South Binion Road; Apopka, FL 32703 USA; cgcampbell@ufl.edu

b Gene McAvoy, Associate Director for Stakeholder Relations, Regional Vegetable Extension Agent IV Emeritus; President, National Association of County Agricultural Agents; University of Florida, Institute of Food and Agricultural Sciences, Southwest Florida Research and Education Center; 2685 State Road 29 North; Immokalee, FL 34142 USA; gmcavoy@ufl.edu
\end{abstract}


agricultural products among Florida residents, leading some grocery stores around the state to commit to buying more produce from Florida growers. A variety of programs and resources to help connect Florida growers to buyers were developed by the University of Florida, Institute of Food and Agricultural Sciences; industry groups; and state and regional organizations. This provides a valuable foundation to support food system resilience for future public health emergencies and natural disasters.

\section{Keywords}

COVID-19, Pandemic, Direct-to-Consumer Sales, Emergency Food Assistance, Cooperative Extension, Food Waste

\section{Florida's Agricultural Sector}

While it is known for theme parks and beaches, Florida's agricultural sector is the second largest industry in the state. It accounts for a substantial proportion of the United States' annual production of many fruit and vegetable crops, such oranges (56\%), grapefruit (54\%), tomatoes $(18 \%)$, watermelon (25\%), cucumbers $(33 \%)$, bell peppers (34\%), squash $(22 \%)$, and green beans $(18 \%)$ (Florida Department of Agriculture \& Consumer Services, 2017; USDA Economic Research Service, 2018). Aside from citrus, peak harvest for these crops is from March to May. During this time, which coincided exactly with the onset of the COVID-19 pandemic, the scale of Florida's crop production is difficult to comprehend. Collectively, South Florida growers ship approximately 60-70 million lb. (27-32 million kg) of vegetables to market every day at the peak of harvest. One growing region alone, Immokalee, accounts for approximately 400-500 semitrailer truckloads (or 15-16 million lb. or 7 million $\mathrm{kg}$ ) of vegetables every day from March through mid-May. Florida's farmers have capitalized on the fact that Florida is a top tourism destination by focusing their production for sales to the theme park, hotel, restaurant, and cruise line industries.

\section{The Impact of the Pandemic on Florida Agriculture ${ }^{1}$}

Shutdowns in response to COVID-19 in Florida and beyond decimated the foodservice market, which accounts for $70-80 \%$ of the sales for Florida's large growers. Because vegetables are highly perishable, after a few weeks, many producers needed to empty their coolers, dump produce, and terminate fields because there was no market for the millions of pounds of fresh produce at peak harvest season. The scale of the loss for Florida producers caused by COVID-19 is difficult to comprehend. Examples abound from South Florida. One grower in Belle Glade disked up 1 million lb. (453,500 kg) of green beans every three days. Another producer plowed under 2 million lb. $(907,000 \mathrm{~kg})$ of green beans and 5 million lb. (2.2 million kg) of cabbage. One farm dumped 100,000 lb. (45,000 kg) of tomatoes in one week. Another producer reported leaving 250 acres (101 hectares) of tomatoes unharvested, losing a US $\$ 2.5$ million investment.

\section{Adaptation and Response}

\section{Direct Sales}

In response to the pandemic, many growers, even large ones, explored alternative market channels, such as direct-to-consumer sales driven by social media campaigns. Traditional commercial farms in South

\footnotetext{
${ }^{1}$ This impact summary was prepared on the basis of information received by Gene McAvoy, who collected information from growers, distributors, and other industry partners throughout the peak harvest season during the COVID-19 pandemic and provided weekly reports from the week of March 23 through the week of May 4, 2020, for University of Florida administration, the Florida Department of Agriculture and Consumer Services, and local government stakeholders.
} 


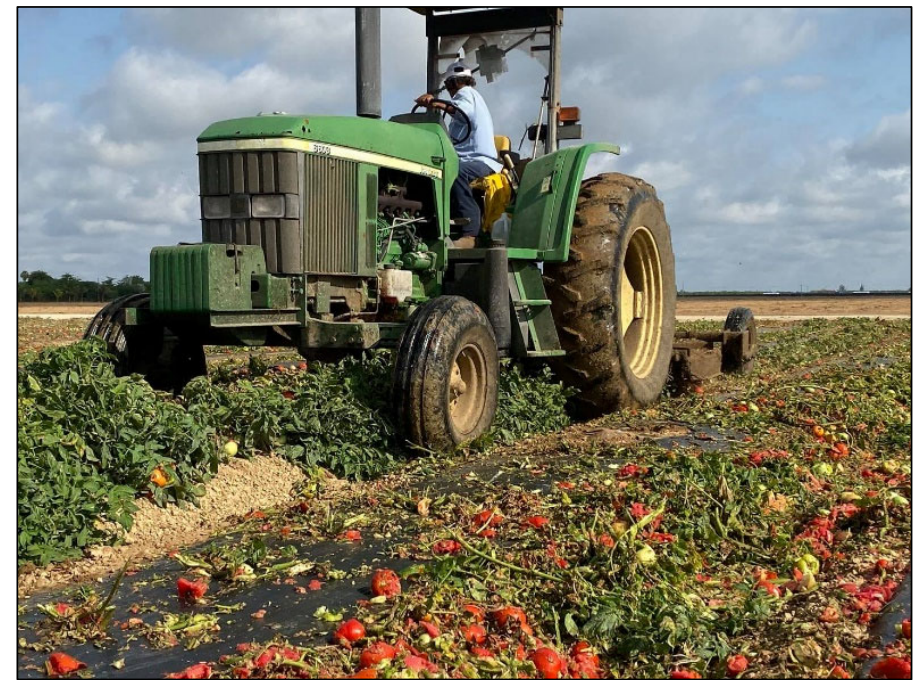

Photo 1. Mowing under the tomato crop. Photo by Gene McAvoy.

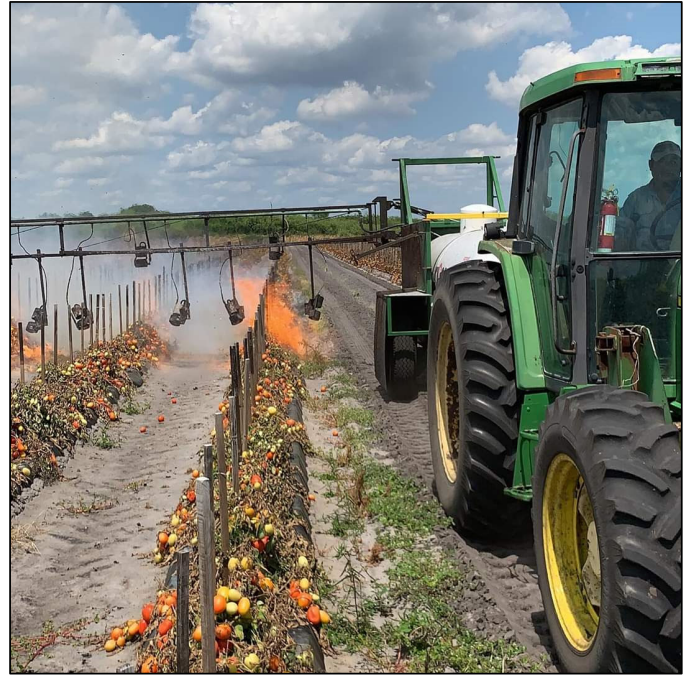

Photo 2. Flaming the tomato crop. Photo by Gene McAvoy.

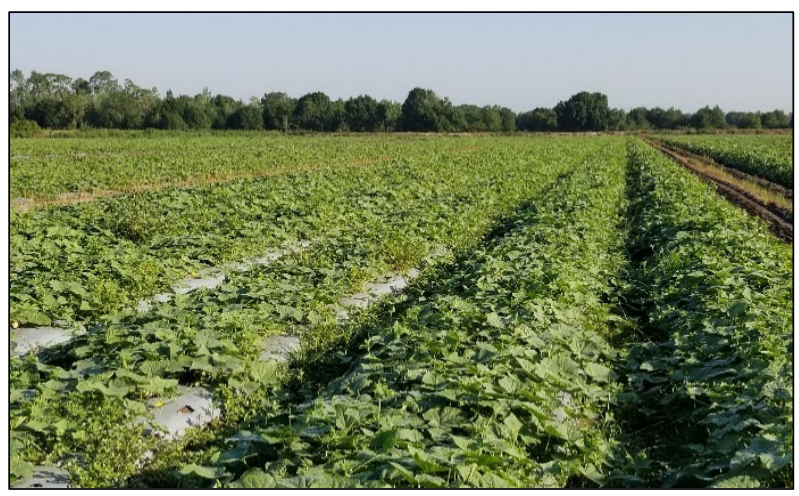

Photo 3. Cucumber field before mowing. Photo by Gene McAvoy.

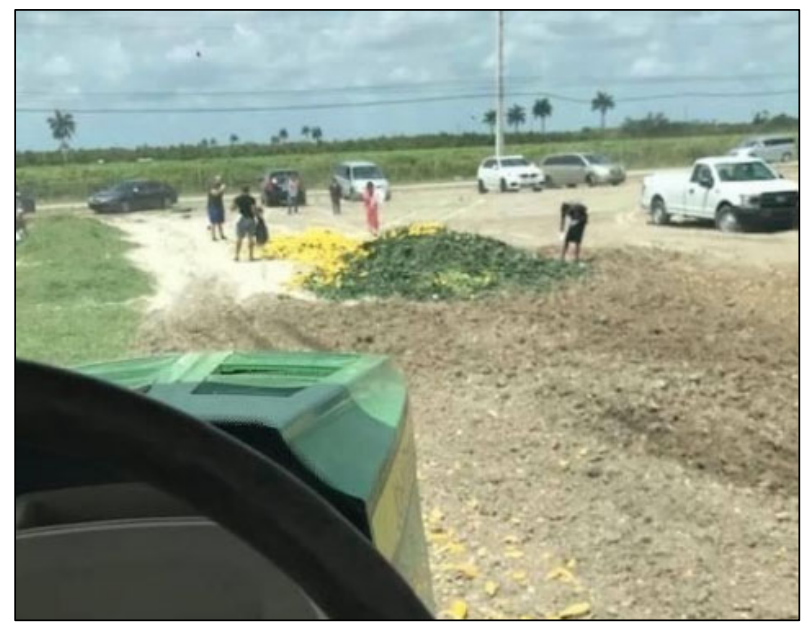

Photo 5. Volunteers gleaning vegetables in Homestead, Florida. Photo by Gene McAvoy.

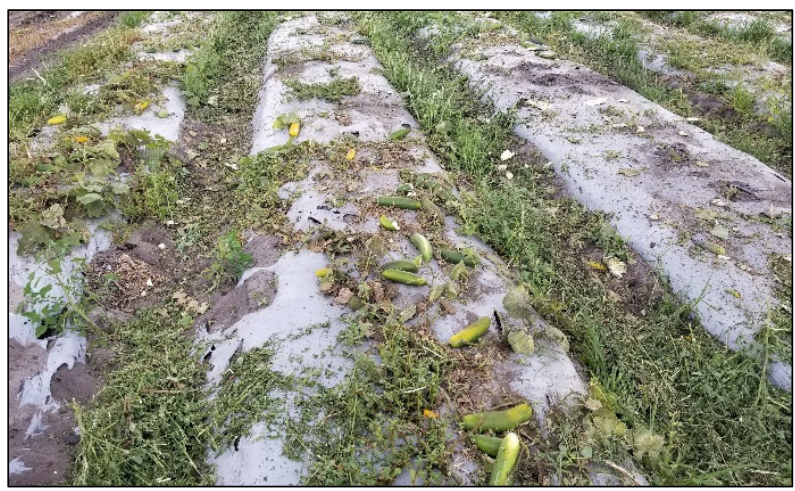

Photo 4. Cucumber field before mowing. Photo by Gene McAvoy.

Florida were overwhelmed by the support for the sales at their packing houses. A packing house in Homestead opened on weekends for direct sales of US $\$ 10$ boxes to consumers and had cars stretched for half a mile in front of the packing house. They sold 120,000 lb. (54,500 kg) of squash, tomatoes, beans, and cucumbers. That packing house partnered with a central Florida farmer to sell 30,000 flats of blueberries at 12 pints for US\$20. One grower in Immokalee opened for direct sales to consumers and had a line of cars stretched for over a mile from before they opened until they closed, with a wait of over an hour and a half. That grower sold 25,000 lb. (11,000 kg) of vegetables that day, although this had limited overall impact - that amount was less than one semi-load, 


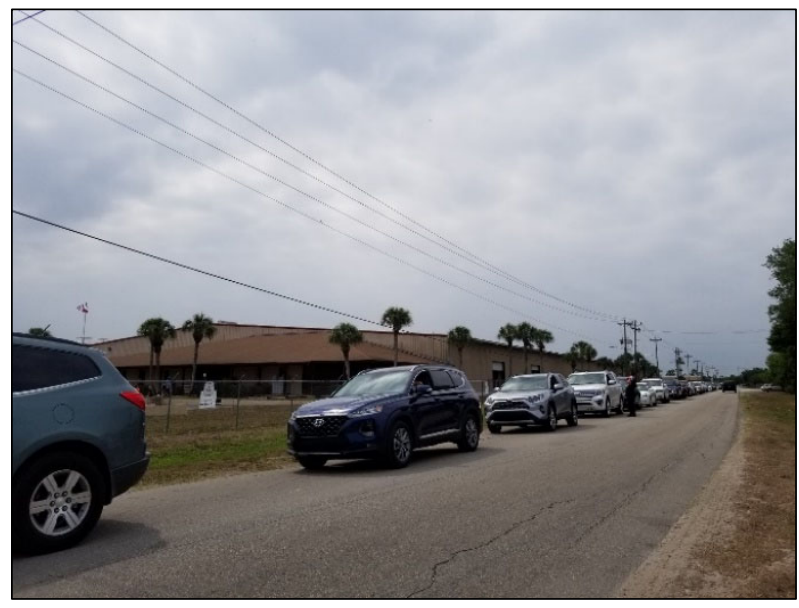

Photo 6. The cars lined up to receive vegetable boxes in Immokolee, Florida, stretched over a mile. Photo by Gene McAvoy.

and that producer would normally ship 10-12 semi-loads a day, every day, at that time of year. Similar efforts were conducted by other farms, packing houses, and nonprofit groups around the state.

\section{Donations}

Despite their substantial financial losses and personal hardship, Florida's growers and shippers went above and beyond by paying to harvest and transport produce to food banks, instead of simply leaving produce in the field. Florida farmers donated millions of pounds of produce to organizations that were overwhelmed with demand from people who recently lost their jobs or were fur-

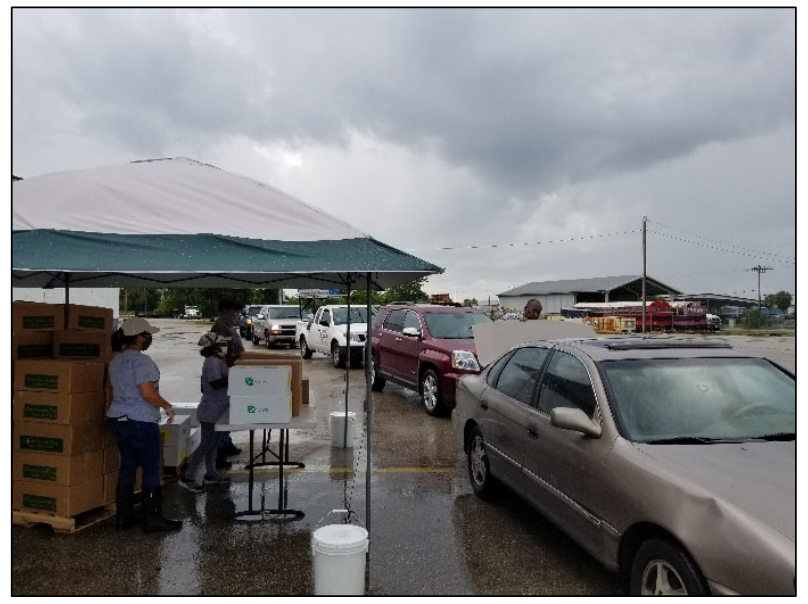

Photo 7. Handing out produce boxes, from farm to family. Photo by Gene McAvoy.

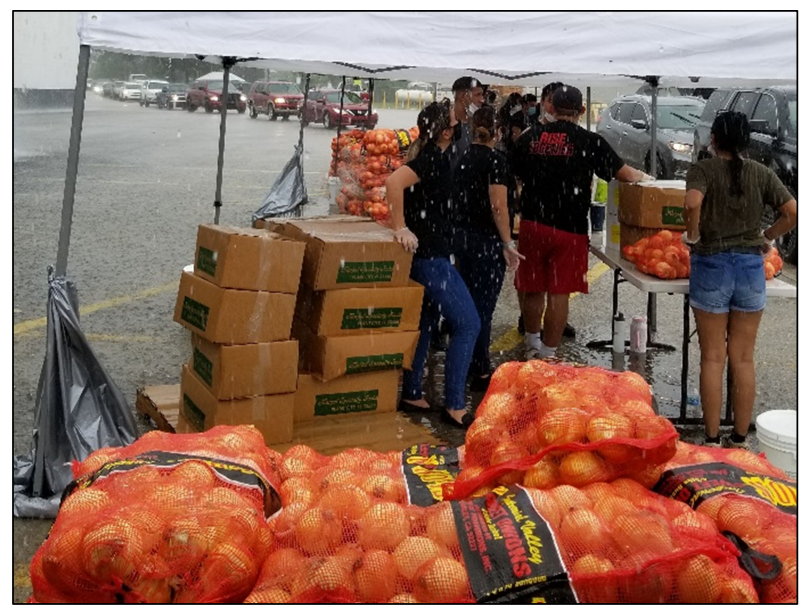

Photo 8. Food distribution in Immokolee, Florida. Photo by Gene McAvoy. loughed due to the closures of restaurants, hotels, theme parks, and cruise lines due to the pandemic.

One farm donated $220,000 \mathrm{lb}$. (100,000 kg) of fresh strawberries-equivalent to nine semi-loads - to a food rescue and distribution organization. One tomato grower donated 42,000 lb. (19,000 kg) of tomatoes to Meals on Wheels PLUS, helping supply 100 food pantries and agencies. Other producers donated tens of thousands of pounds of fresh green beans, sweet corn, and cabbage to food banks throughout the state. Florida's sugar producers, who are also major producers of other vegetables such as sweet corn, green beans, cabbage, and leafy greens, provided thousands of crates of fresh, locally grown produce to their employees, food banks, churches, and healthcare centers in South Florida. Growers in Immokalee donated more than 3 million $\mathrm{lb}$. (1.4 million $\mathrm{kg}$ ) of vegetables to a Southwest Florida food bank, overwhelming their ability to store, transport, and distribute the produce. Unfortunately, there is only so much perishable food that charities—with limited numbers of refrigerators and volunteers—can absorb.

Florida sugar producers went beyond crop donations by supporting a program that provided 15,000 hot meals from local restaurants to local residents. One sugar producer donated 15,000 N95 masks to local hospitals and first responders. Finally, one sugar producer had a unique response to the coronavirus 
pandemic by donating 42,500 lb. (19,000 kg) of sugar to a rum distillery to make into hand sanitizer for donation to first responders, hospitals, nursing homes, and essential food supply employees.

\section{What This Means for the Future}

The catastrophic impact of the pandemic has led to increased public awareness of Florida's agricultural industry. It also led to a variety of support programs to help connect Florida growers to buyers, which provides a valuable foundation to support food system resilience for future public health emergencies and natural disasters. ${ }^{2}$ In response to consumer demand, some grocery stores around the state have committed to buying more produce from Florida growers and now actively advertise using the Fresh from Florida labeling, a state marketing program for Florida agricultural products. Finally, many growers are engaging with new direct sales opportunities and using technology to connect with consumers who are newly aware of the importance of supporting Florida farmers. Looking to the future, these initiatives connecting producers to consumers will yield a more resilient food system in Florida.

\section{References}

Florida Department of Agriculture \& Consumer Services. (2017). Florida agriculture overview and statistics. Retrieved from https://www.fdacs.gov/Agriculture-Industry/Florida-Agriculture-Overview-and-Statistics

U.S. Department of Agriculture, Economic Research Service. (2018). Cash receipts by state [Farm Income and Wealth Statistics]. Retrieved from https://data.ers.usda.gov/reports.aspx?ID=17843\#P0c8dbba5081545ae88c86a9e797196c0 5 79iT0R0x9T0

\footnotetext{
${ }^{2}$ See, for example, Florida Department of Agriculture and Consumer Services (FDACS) "Florida Farm to You" program (https://www.fdacs.gov/Agriculture-Industry/Florida-Farm-To-You), the Southwest Florida Fresh website (https://www.swflfresh.com/), developed by University of Florida, Institute of Food and Agricultural Sciences Extension in collaboration with the Southwest Florida Regional Planning Council.
} 